EFFicieNT

\title{
Money Supply, Counterfeit Money, and Economic Growth Effect to E-Money Transaction
}

\author{
Chintia Ariani Putri $^{1 凶}$, P. Eko. Prasetyo ${ }^{2}$ \\ Jurusan Ekonomi Pembangunan, Fakultas Ekonomi, Universitas Negeri Semarang
}

Permalink/DOI: https://doi.org/10.15294/efficient.v3i1.35951

Received: July 2019 ; Accepted: October 2019 ; Published: January 2020

\begin{abstract}
Electronic money is an innovation in payment systems. Although transactions continue to increase, the ratio of electronic money transactions to transactions using the Card Payment Instrument is always less than $1 \%$. The purpose of this study is to determine the effect of monetary instruments namely the money supply (M1), counterfeit money, and economic growth on electronic money transactions in Indonesia. This research uses a quantitative method using time series data during the period January 2016 - December 2018. Data analysis uses multiple linear regression with a double log model based on OLS. The results of this study indicate that the money supply $(\mathrm{Mr})$ has a positive and significant effect on electronic money transactions, counterfeit money has no significant effect on electronic money transactions, economic growth has a positive and significant effect on electronic money transactions. The implication of this research is that electronic money should be given additional security such as PIN so that when the owner loses it will not lose the balance contained therein, Bank Indonesia should encourage and encourage the public to switch to using electronic money so that it can reduce the money supply and avoid the risk of counterfeit money.
\end{abstract}

Keywords: Electronic Money, Money Supply, Counterfeit Money, Economic Growth

\begin{abstract}
Abstrak
Uang elektronik merupakan inovasi dalam sistem pembayaran. Meskipun transaksi terus meningkat, rasio transaksi uang elektronik dengan transaksi menggunakan Instrumen Pembayaran Kartu selalu kurang dari 1\%. Tujuan dari penelitian ini adalah untuk mengetahui pengaruh instrumen moneter yaitu jumlah uang beredar $(\mathrm{Ml})$, uang palsu, dan pertumbuhan ekonomi pada transaksi uang elektronik di Indonesia. Penelitian ini menggunakan metode kuantitatif menggunakan data deret waktu selama periode Januari 2016 - Desember 2018. Analisis data menggunakan regresi linier berganda dengan model log ganda berdasarkan OLS. Hasil penelitian ini menunjukkan bahwa jumlah uang beredar (Mi) berpengaruh positif dan signifikan terhadap transaksi uang elektronik, uang palsu tidak berpengaruh signifikan terhadap transaksi uang elektronik, pertumbuhan ekonomi berpengaruh positif dan signifikan terhadap transaksi uang elektronik. Implikasi dari penelitian ini adalah bahwa uang elektronik harus diberikan keamanan tambahan seperti PIN sehingga ketika pemilik kehilangan itu tidak akan kehilangan saldo yang terkandung di dalamnya, Bank Indonesia harus mendorong dan mendorong masyarakat untuk beralih menggunakan uang elektronik sehingga dapat mengurangi jumlah uang beredar dan menghindari risiko uang palsu
\end{abstract}

Kata Kunci: Uang Elektronik, Jumlah Uang Beredar, Uang Palsu, Pertumbuhan Ekonomi

How to Cite: Putri, C., \& Prasetyo, P. (2020). Money Supply, Counterfeit Money, and Economic Growth Effect to E-Money Transaction. Efficient: Indonesian Journal of Development Economics, 3(1), $634-649$. https://doi.org/10.15294/efficient.v3i1.35951

(C) 2019 Semarang State University. All rights reserved

\footnotetext{
Alamat Korespondensi :

Alamat: Gedung L2 Lantai 2 FE Unnes

Kampus Sekaran, Gunungpati, Semarang, 50229

E-mail : chintiaarianiı@gmail.com
}

ISSN 2655-6197 


\section{INTRODUCTION}

Current technological developments continue to experience progress and develop rapidly, including technological developments in the payment system. With the development of computers and the expansion of internet network access, the creation of an efficient payment service system is increasingly possible. The payment system is a system related to the activities of transferring funds from one party to another involving various components of the payment system, including payment instruments, clearing, and settlement (Bank Indonesia, 2008).

In general, non-cash payments are made by transferring between banks through the bank's internal network. Non-cash payments can also be made with cards as payment instruments such as ATM cards, debit cards and credit cards (Lintangsari, 2018). At present a non-cash payment instrument has emerged that has the same function as cash, namely electronic money or commonly referred to as e-money (electronic money). E-money is an innovation in the field of payment instruments created to replace cash payment instruments. Electronic money offers better features in transaction speed and convenience compared to credit and debit cards (Suseco, 2016).

In the provisions of Bank Indonesia Regulation Number 20/6/PBI/2018 concerning Electronic Money in the provisions of Article 1 Paragraph 3, Electronic Money is a payment instrument that meets the following elements: Issued based on the value of money paid in advance to the issuer; The value of money is stored electronically on a media server or chip ;; The value of electronic money managed by the issuer is not a deposit as referred to in the Act governing banking.

While ATM cards, debit cards or credit cards are cards whose value of money is stored in the customer's account in question in the bank, while in electronic money, the value of the money is stored in computer system devices, cellphones, prepaid cards or chip cards. When an electronic money holder makes a payment or fund transfer transaction, the value of the money contained in the electronic money will also be reduced in accordance with the value of the payment transaction or fund transfer carried out, such as in using cash. Conversely the value of money in electronic money can increase when receiving payments or when refilling (Tazkiyyaturrohmah, 2018).

In 2007, Bank Indonesia began to regulate the use of electronic money into APMK (Card-Based Payment Instrument). Then on April 13, 2009 Bank Indonesia issued Bank Indonesia Regulation no. 11/12 / PBI / 2009 concerning Electronic Money. With the issuance of the Bank Indonesia Regulation (PBI), as of April 13, 2009, the regulation concerning Electronic Money is separate from the regulation regarding Card-Based Payment Instruments (APMK). This Bank Indonesia Regulation concerning Electronic Money contains provisions including but not limited to procedures for licensing and transferring licenses, procedures for administration, supervision, enhancing technological security and sanctions.

The impact of the issuance of this PBI on electronic money indirectly results in the increasing number of electronic money usage, until now the number of electronic money users and their transactions continues to 
increase every year. This was also driven by policies issued by Bank Indonesia (BI) which have allowed certain types of e-money issued by banks, cellular operators, and other parties. As of May 2019, the 38 electronic money providers had been registered as licensed by Bank Indonesia. The increase in electronic money users is also supported by the increasing number of shopping centers, restaurants, and cafes, even street vendors (street vendors) in Indonesia who accept payment transactions using a non-cash payment system. (Abidin, 2015)

The following data shows the nominal number of electronic money transactions in Indonesia from the beginning of the issuance of Bank Indonesia Regulation Number 11/12 / PBI / 2009 concerning Electronic Money in 2009 to 2018 :

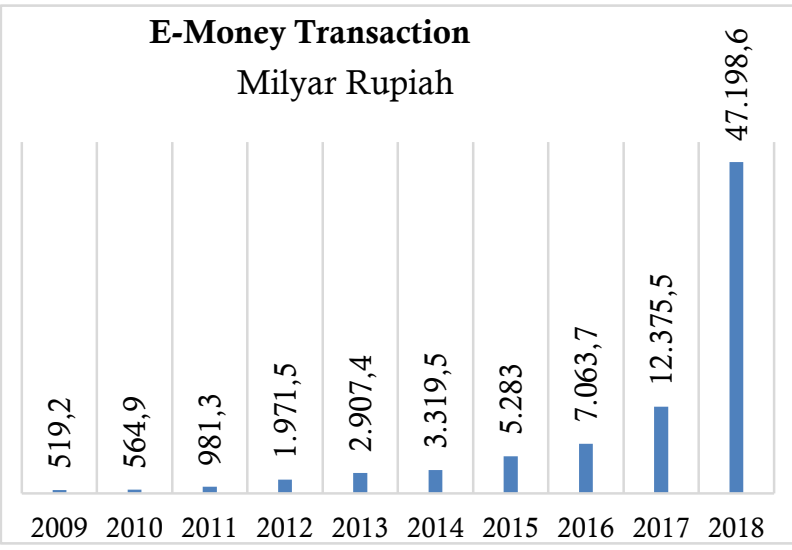

Figure 1. Electronic Money Transactions in Indonesia

Source: Bank Indonesia, 2019

Electronic money transactions in Indonesia show a positive trend, in Figure 1 the electronic money transactions have increased every year. The highest increase in electronic money transactions occurred in 2017 towards
2018, amounting to $\mathrm{Rp} 34.8$ trillion due to the use of e-tolls. Based on the Minister of Public Works and Public Housing Regulation Number 16/prt/m/2017 regarding non-cash toll transactions on toll roads, currently toll users are required to pay tolls by the electronic system or e-toll.

Although electronic money transactions continue to increase every year, the number of electronic money transactions is still very small compared to APMK transactions, namely ATM/Debit cards and Credit cards. Since the beginning of electronic money issued, the ratio of electronic money transactions to other noncash transactions every year has always been less than $1 \%$. This shows that electronic money transactions have a very small contribution to support non-cash payments and to realize the Less Cash Society movement or the community without cash.

Electronic money transactions since the issuance of PBI in 2009 until 2018 have experienced a significant increase, but these transactions are considered to be very small compared to APMK transactions, so the ratio of electronic money to non-cash transactions is considered to be very small. Therefore, Bank Indonesia has always been make various efforts to continuously improve the electronic money transaction. To reduce the money supply, such as currency, a PBI was issued on money electronic indirectly used so that people switch to using electronic money and is expected to encourage the realization of a society without cash (cashless society). The following table shows the ratio of electronic money transactions to APMK.

From table 1 . it can be seen Bank Indonesia cooperates with banks and also the 
government to create a cashless society that aims to increase public awareness of the use of non-cash payments to form a community or community that uses non-cash payments in conducting transactions for economic activities. In terms of efficiency, cashless society can reduce the budget that is issued each year to print money. (Tazkiyyaturrohmah, 2018).

Table 1. E-Money Transaction Ratio Against APMK Transaction

\begin{tabular}{|c|c|c|c|c|}
\hline Year & $\begin{array}{l}\text { Number of APMK } \\
\text { Transactions }\end{array}$ & $\begin{array}{l}\text { Number of } \\
\text { Transactions }\end{array}$ & E-Money & E-money Ratio to APMK \\
\hline 2009 & 1.948 .188 .235 .000 .000 & 519.213 .000 .000 & & $0,03 \%$ \\
\hline 2010 & 2.165 .061 .693 .000 .000 & 564.927 .000 .000 & & $\mathrm{o}, \mathrm{ol} \%$ \\
\hline 2011 & 2.658 .633 .067 .000 .000 & 981.297.000.000 & & $0.04 \%$ \\
\hline 2012 & 3.266.920.778.00o.ooo & 1.971.550.000.000 & & $0,06 \%$ \\
\hline 2013 & 4.020.740.015.000.000 & 2.907.432.00o.0oo & & $0,07 \%$ \\
\hline 2014 & 4.696.387.970.000.000 & 3.319.556.000.000 & & $0,07 \%$ \\
\hline 2015 & 5.178 .338 .365 .000 .000 & 5.283.018.00o.ooo & & $0,10 \%$ \\
\hline 2016 & 5.904.933.164.000.000 & 7.063 .689 .000 .000 & & $0,11 \%$ \\
\hline 2017 & 6.498.198.865.00o.ooo & 12.375.469.000.000 & & $0,19 \%$ \\
\hline 2018 & 7.269.428.229.000.000 & 47.198.616.000.000 & & $0,64 \%$ \\
\hline
\end{tabular}

Source : Bank Indonesia, 2019

The Bank Indonesia Statistics and Monetary Direktroat Team in 2006 was referred to enter the balance contained in emoney into part of the money supply in a narrow sense $(\mathrm{M} 1)$, but $\mathrm{M} 1$ so far only consists of currency and demand deposits, while the understanding of e-money according to Bank Indonesia to date has not explained the clarity of classes of funds contained in e-money in terms of the money supply both on Mi and on M2. So by reducing the money supply, it is expected to be able to divert and increase the public to use e-money. The discovery of counterfeit money is also one of the factors that is considered to influence the increasing public interest in using electronic money. Until now the circulation of counterfeit money is still found in the community. Based on this, BI urged the public to use non-cash payments to reduce and narrow the circulation of counterfeit money. Benefits in using non-cash transactions such as debit cards, e-money to credit cards can prevent victims of the circulation of counterfeit money. The following are the findings of counterfeit money in Indonesia from 2011 to 2018 :

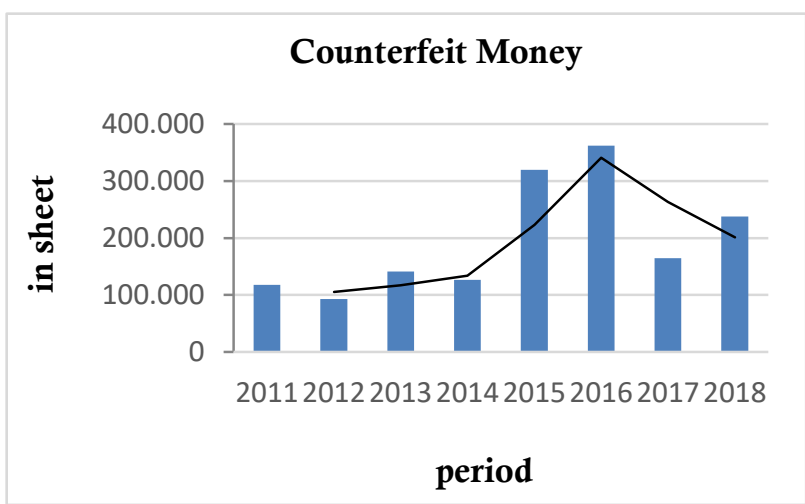

Figure 2. Counterfeit Money Findings

Source: Bank Indonesia, 2019 
Figure 1. shows the number of counterfeit money findings from 2011 to 2018 fluctuating. A sharp increase in the findings of counterfeit money was found in 2014 of 126,417 shares leading to 2015 totaling 319,681 shares. The highest invention of counterfeit money was found in 2016 with 362,250 shares. The relatively high invention of counterfeit money is one of the triggers for Bank Indonesia to encourage the public to switch to using electronic money because by using electronic money transactions conducted by the public will be safer because it can avoid the risk and it is no longer easy to find counterfeit money.

Economic growth can also be regarded as one indicator of increasing electronic money transactions. In brief, the understanding of economic growth is according to the process of increasing output per capita in the long run (Boediono, 2009: 1). The basic approach to measuring a country's economy is Gross Domestic Product (GDP). Todaro (2003) suggests that the welfare of the middle to lower classes can be represented by the level of community life. The standard of living of the community is marked by the alleviation of poverty, a better level of health, an acquisition of a higher level of education, and a level of community productivity. Based on this the people's welfare can be seen from the output level of productivity through high GDP values which then present economic growth.

This is supported by research conducted by Olena Slozko (2014) that a high level of welfare and the development of the financial system can encourage transactions without cash. According to Todaro, there are three main factors or components in the economic growth of each nation, the three of them are:
Capital accumulation which includes all forms or types of new investments invested in land, physical equipment and capital or human resources, Population growth in the next few years increase the amount of capital accumulation, technological progress (Pujiati, 2011).

Electronic money is the development of a new payment system that is now very popular with the public. Although electronic money transactions continue to increase every year, the transaction ratio is still very small compared to other non-cash transactions such as APMK and it is considered that electronic money still has a controversy to encourage the Less Cash Society. This study aims to determine the factors that influence the increase in electronic money transactions from the monetary side. Based on this, the formulation of the problem in this study is as follows: how the influence of the money supply (Mi) on electronic money transactions in Indonesia, how the influence of the circulation of counterfeit money on electronic money transactions in Indonesia, how the influence of economic growth on electronic money transactions in Indonesia, how the influence of the money supply, counterfeit money, and economic growth on electronic money transactions together.

The implications of this study are as follows: to find out whether the money supply (Mi) can affect electronic money transactions in Indonesia, to find out whether the circulation of counterfeit money can affect electronic money transactions in Indonesia, to find out whether economic growth can affect electronic money transactions in Indonesia , to find out whether the money supply, 
counterfeit money, and economic growth can affect electronic money transactions together. In his book, Mankiw argues that the more money needed to transact, the more money will be held. So, the quantity of money in an economy is very closely related to the amount of money used in transactions.

Fisher argues that the acceleration of the velocity of money is determined by institutions in the economy that affect the way individuals conduct transactions. If more and more people use debit cards or credit cards in the transaction, there will be fewer people using currency as a transaction tool, the less amount of money needed to conduct transactions generated by nominal income so that the acceleration of the velocity of money will increase. Conversely, if people prefer to use cash or checks in their transactions, more money will be used to make transactions generated by the same nominal income, so that the acceleration of the velocity of money will decrease. Although the true increase in the velocity of money is still dominated by currency. (Mishkin, 2008: 187)

The money supply (money supply) is the total stock of money in the economy in a certain period which is usually within one fiscal year (Lapong, 2016.). According to Solikin \& Suseno (2002) we currently know of only two types of money supply, namely: Money in the strict sense, which is often given the symbol $\mathrm{M} 1$, namely the monetary system obligations to the domestic private sector consisting of currency (C) and demand deposits (D), and circulating Money in a broad sense, which is often also referred to as economic liquidity and given the symbol M2, namely the monetary system obligations to the domestic private sector consisting of currency
(C), demand deposits (D), and quasi money ( $\mathrm{T})$. In other words M2 is M1 plus quasi money (T).

Based on PBI No. 16/8 / PBI / 2014 concerning Amendments to Bank Indonesia Regulation No 11/12 / PBI / 2009 concerning Electronic Money, e-money issued by banks or institutions outside banks that have fulfilled the requirements of Bank Indonesia which are also generally electronic money issuers This is called the issuer. This issuer maintains a floating fund, which is the entire value of electronic money received by the issuer for the results of the issuance of electronic money and/or top-up which is still an obligation of the issuer to holders and traders.

The Bank Indonesia Statistics and Monetary Direktroat Team in 2006 referred to include e-money float funds as part of the money supply in a narrow sense (Mi), where Mi so far only consisted of currency outside banks (currency) and demand deposits (demand deposits), while the definition of emoney according to Bank Indonesia to date has not explained the clarity of classes of emoney float in terms of the money supply both on M1 and M2. The basis of this opinion is that float funds are funds belonging to customers or merchants who use e-money that can be used as a means of payment at any time, so that the nature of float e-money is very liquid, or can be equated with cash (cash) or demand deposits, then the float e-money should be calculated as part of Mi. So by reducing the money supply, it is expected to be able to divert and increase the public to use e-money.

Based on research conducted by Utami and Kusumawati (2017) some of the advantages of using e-money first are providing convenience in the payment transaction 
quickly and safely for the wider community. Second, the problem of cash handling can be solved, which has often been experienced when using cash as payment for the industry. Third, improve the efficiency of money printing and multiplying money for Bank Indonesia. Tazkiyyaturrohmah (2018) states that aside from its ease and practicality, electronic money has several advantages compared to conventional banknotes, one of which can minimize the circulation of counterfeit money so that it can reduce the crime rate because there is no need to carry cash anywhere. Besides according to Ramdani (2014) currency has several weaknesses, one of which is the amount of counterfeit money in circulation and is very similar to the original, causing counterfeit money to deceive ordinary people.

One step to avoid counterfeit money is to encourage people to use electronic money. Until the end of 2018 there were still 16,170 bills circulating in the community. Therefore, this is used by Bank Indonesia to be able to invite the public to be able to switch using electronic money, so the circulation of counterfeit money is one of the factors that can affect electronic money transactions.

Economic growth is one indicator that is used to look at a country's economic conditions through the rate of GDP or GNI. Through economic growth, an indication of the economic activity of a country can be known and its benefits for the people of that country in a certain period. Economic growth is briefly interpreted as a process of increasing output per capita in the long run. The emphasis is on three aspects, namely process, per capita output increase and in the long run (Prasetyo, 2009: 18).

According to Todaro, there are three main factors or components in the economic growth of each nation, the three of them are: Capital accumulation which includes all forms or types of new investments invested in land, physical equipment and capital or human resources, Population growth in the next few years increase the amount of capital accumulation, technological progress. (Maqrobi \& Pujiati, 2011) The use of economic growth indicators will usually be seen within a certain period, for example one year. The rate of economic growth will be measured through indicators of GDP or GNI growth from year to year. Gross Domestic Product (GDP) can be interpreted as the value of goods and services produced in the country in a given year. Goods and services produced are not only those produced by companies owned by the country's population but by residents of other countries that are located or producing in the country (Sukirno, 2011: 34-35).

According to Suseco (2016), one method to measure the value of GDP is through adding all household income in the form of wages and salaries, profits, rent and interest earned from the production of goods and services. Todaro (2003) suggests that the welfare of the middle to lower classes can be represented by the standard of living public. The standard of living of the community is marked by the alleviation of poverty, a better level of health, an acquisition of a higher level of education, and a level of community productivity.

Based on this the welfare of the community can be seen from the output of the 
level of productivity through high GDP Values then presenting economic growth. According to Olena Slozko (2014), a high level of welfare and the development of the financial system can encourage transactions without cash.

\section{METHOD}

This type of research uses the type of quantitative research, which is related to data in the form of numbers and statistical programs. The design of this study uses hypothesis testing which aims to analyze, describe and obtain empirical evidence about the influence between variables that have been hypothesized in this study. The data used in this study are secondary data consisting of data on the number of electronic money transactions, the money supply ( $\left.\mathrm{Ml}_{1}\right)$, counterfeit money and economic growth vulnerable from January 2016 to December 2018 or as many as 36 samples. Sources of data in this study can be obtained from recording or copying data contained in Bank Indonesia publications and the Central Statistics Agency. The data used are time series data on a monthly scale.

The dependent variable in this study is electronic money transactions in Indonesia which shows the nominal magnitude of electronic money transactions and is measured in trillion rupiahs. The independent variables used in this study are the money supply (M1), counterfeit money and economic growth.

The Amount of Money Supply (JUB) as variable $\mathrm{X}_{1}$, this study uses the notion of the amount of Money Supply in the narrow sense (M1). This variable is measured in units of billions of rupiah. Counterfeit Currency as variable $\mathrm{X}_{2}$, and measured in units of sheets.
Economy Growth as variable $\mathrm{X}_{3}$, and is measured in percent units.

The method used for data collection in this study is the method of documentation and study of literature from several institutions or institutions of the domestic government. These institutions are Bank Indonesia (BI) and the Central Statistics Agency (BPS). The method of literature study conducted in this research is by studying literature, exploration, and studying literature such as magazines, journals, and other sources relating to the research conducted. The processing technique in this study uses multiple regression analysis (multiple regression analysis) using a double log model based on OLS (Ordinary Least Square). This study aims to determine whether the independent variables, namely the amount of money in circulation, counterfeit money, and economic growth have a significant effect on the dependent variable, namely electronic money transactions.

The multiple regression analysis in this research is used to find out how much influence the money supply $(\mathrm{Mr})$, counterfeit money, and economic growth has on electronic money transactions in Indonesia. So the above research can be made as follows:

$\log Y=\beta_{0}+\beta_{1} \log X_{1}+\beta_{2} \log X_{2}+\beta_{3} \log X_{3}+$ e..

Explanation:

$\mathrm{Y}=$ Electronic Money Transaction

$\beta \mathrm{o}=$ constant (constant)

$\beta_{1}-\beta_{3}=$ regression coefficient

$\mathrm{X}_{1}=$ Amount of Money Supply

$\mathrm{X}_{2}=$ Counterfeit Money

$\mathrm{X}_{3}=$ Economic Growth

$\mathrm{e}=$ error 
Classical assumptions are requirements that must be met in the Ordinary Least Squares (OLS) model. The goal is to produce an estimated parameter value that matches the actual value, so that the parameter value has an unbiased, consistent, and efficient characteristic or commonly referred to as Best, Linear, Unbiassed Estimator (BLUE) (Wahyudi, 2016).

The classic assumption tests used in this study are: Normality Test, Autocorrelation Test, Multicollinearity Test, and Heteroscedasticity Test. Significance test of individual parameters (statistical t-test) means testing the regression coefficients individually to find out the significance of the partial role between the independent variables in influencing the dependent variable by assuming that other independent variables are considered constant using a 5 percent degree of trust (Ghozali, 2013: 97) . F-test is done to find out how far the independent variables or independent variables together can affect the dependent or dependent variable (Bawono, 2006: 91). To find out how far the independent variable influences the dependent variable can also be done through the coefficient of determination test $\left(\mathrm{R}_{2}\right)$. Or it can be said that the coefficient of determination $\left(R_{2}\right)$ is used to see the percentage of the effect of variables $X_{1}$, $\mathrm{X}_{2}$, and $\mathrm{X}_{3}$ affect the variable $\mathrm{Y}$.

\section{RESULTS AND DISCUSSION}

Based on the results of the multiple regression analysis conducted, it is known that there is a one-way relationship between the money supply (M1) and electronic money transactions that can be seen from the probability of the money supply being less than 0.05 . The money supply has a significant positive effect on electronic money transactions in Indonesia, where an increase in the money supply will increase transactions for electronic money. Although many people have started using electronic money, cash is still a necessity that cannot be abandoned.

This is because there is still a public perception about not having money if there is no physical presence, so the money supply (Mi) continues to increase accompanied by an increase in electronic money transactions where currently more and more public facilities are using electronic money as a payment system such as tolls, restaurants, cafe, supermarkets and other places. The increase in electronic money is also supported by the increasing number of merchants both from financial institutions and non-financial institutions that issue electronic money. Another factor that influences the high public interest in the use of electronic money is due to the attractiveness of promotions and various kinds of benefits that will be obtained when using electronic money in addition to being faster and more efficient, namely due to discounts and cashback.

At present the economic system leads to a more efficient and effective economy, namely the use of technology. To move towards an efficient and effective economy, the Less Cash Society (LCS) movement emerged, which is a movement to reduce the use of cash to switch to using non-cash money in conducting transactions. The money supply is the amount of money in the community in the form of currency, demand deposits, and savings. But in 2007 in Indonesia came 
electronic money that had the same function a currency and was used by the public for transactions. Money according to Sukirno (2011: 267) is defined as objects agreed to by the community as an intermediary tool for exchanging or trading. Approved by the community means that there is an agreement by the general public to use one or several objects as an intermediary tool in the exchange activity. Money in general is something that can be generally accepted as a means of payment in a particular area or as a means of payment of the debt, or as a tool for making purchases of goods or services. In other words, money is a tool that can be used in a particular area (Mujahidin, 2007: 45).

According to Siti Hidayati's research (2006), balances contained in electronic money should have been classified as part of the money supply in a narrow sense (M1), but because it turns out that this electronic money account is not fully liquid, it can occur if this electronic money account empty value. So even though there is a statement that what is calculated in terms of $\mathrm{Mr}$ is the float fund of electronic money alone, however, BI has not determined electronic money as one part of the money supply in the narrow sense $(\mathrm{Ml})$.

This understanding brings understanding that encouraging the use of electronic money can be done by reducing the circulation of money in the community. As stated by Bank Indonesia Pekanbaru branch which took the initiative to reduce the money supply to increase the use of electronic money. It is theoretically quite clear how people will make requests for electronic money which is quite a lot and uses electronic money in transactions if the amount of money circulating in the narrow sense is reduced, then the public can use their savings to transact by transferring it to their electronic money account.

In reality this is not the case, to reduce the money supply by inviting people to switch to using electronic money does not seem to be appropriate. Because based on data released by Bank Indonesia, it shows that the money supply $(\mathrm{M} 1)$ continues to increase every year. In general, people start using electronic money or asking for electronic money when they have money physically (currency) in their excessive hands, thereby increasing the money supply will encourage them to start saving or moving their money in electronic money, for those who already have a proper understanding of the definition of electronic money and its benefits in fact. (Nadia Suci Anugrah, 2017).

Data shows how from 2007 both electronic money and the money supply continued to increase. Neither of them didn't experience a decline every year until 2014. In fact, when examined carefully it was seen that the addition of changes in the quantity of electronic money demand each has decreased, except in 2013. In 2012 there was a decrease in changes in the quantity of money supply that had previously continued to increase. However, this cannot be said that the decrease in changes in the money supply in that year was a factor that influenced an increase in changes in demand for electronic money because in the following year the change in the quantity of electronic money demand also declined. Therefore it appears that the trend of both variables is a positive trend.

Increasing the money supply to support the public to have money to deposit it in their electronic money accounts is not true. This is due to the increased money supply which is 
not necessarily distributed evenly through their income. The money supply increase, especially M1 which is increasingly pushed it will tend to cause inflation. So that people who have the currency will continue to use paper money and coins because of their understanding that the currency was more liquid than money electronic. They do not have enough money to open electronic money due to higher expenditure when inflation occurs.

According to Prathama and Mandala research (2008: 324) states that technically the money supply is money that is really in the hands of the community. The development of the money supply reflects the development of the economy. A growing and developing economy causes the money supply to increase. If the economy is more advanced, the portion of the use of currency (paper money and coins) is getting less, replaced by demand deposits. The economy is progressing and the composition of $\mathrm{M}_{1}$ in the circulation of money is getting smaller because the portion of quasi money is getting bigger. Advances in technology in the payment system have replaced the role of cash in the form of noncash payments that are more efficient and economical.

According to Pramono (2006), the banking and non-banking sectors are increasingly innovative in providing various alternative non-cash payment services in the form of transfer systems and payment instruments that use electronic cards (electronic card payments) that are safe, fast and efficient, and are global due to the development of information technology and followed by a higher level of bank competition.
Sova (2013) stated that "the growing use of electronic money should reduce the share of banknotes and coins in the narrow money supply and a decrease in the share of bank transfers". The increase in electronic money should reduce the money supply in the narrow sense (M1) that exists in society. And Suseco (2016) which states that "By reducing the use of banknotes, the transaction will run faster and bigger". By reducing the use of banknotes, transactions will run faster and bigger. Bank Indonesia believes that the national non-cash movement program, especially for the use of electronic money for payments at the Automatic Toll Gate (GTO), can minimize the use of coins.

Based on the results of multiple regressions that have been made, note counterfeit money has no significant effect on electronic money transactions. This can be seen from the probability value of money greater than 0.05 so it can be said that the increase in counterfeit money has no significant effect on electronic money transactions. Based on research conducted by Tazkiyyaturrohmah (2018) which states that in addition to its ease and practicality, electronic money has several advantages compared to conventional banknotes, namely one of which can minimize the circulation of counterfeit money so that it can reduce the crime rate because there is no need to carry cash anywhere .

In accordance with Article 1 of Law No. 7 of 2011 concerning Currency, counterfeit Rupiah is an object whose material, size, color, image, and/or design resembles Rupiah that was created, formed, printed, duplicated or circulated, is not used as a payment 
instrument by demeaning Rupiah's honor as a symbol of the State. Everyone is prohibited from spreading or circulating fake Rupiahs. The felony Rupiah crime is threatened with a maximum of 1 (one) year imprisonment and a maximum fine of Rp. 200,00o,00o. Counterfeit money is not a new form of criminality in the community. merchant owners can book cash more transparently. Potential fraud by employees can be minimized because the funds from the transaction directly enter the merchant's bank account.

Factors that can increase public interest in using electronic money is because the currency that is often used in each transaction has many weaknesses, the first is that currency is considered less practical. Cash transactions will run inefficiently because the buyer must carry a currency equal to the price of the goods, it is considered less practical and able to invite crime. Second, the seller will find it difficult to give change even sometimes ignores the right of the buyer to get change, or give change only with goods that are roughly the same price as the change. Third, the amount of counterfeit money in circulation and very similar to the original cause people cannot distinguish between real money and counterfeit money. Counterfeit money in circulation and very similar to the original cause the fake money can deceive ordinary people (Ramdani, 2014). And finally the weakness of currency is the enormous cost of printing currency.

The use of high cash certainly has an impact on the burden of high management costs ranging from printing, distribution, processing to annihilation. Communities also often experience difficulties in transaction because of the limited availability of certain fractions. The use of cash in the community carries the risk of being used in criminal activities because transactions are difficult to trace. The use of cash also complicates development planning because many transactions are not recorded in official calculations. So with the use of electronic money is expected to reduce all these problems. Although still in its early development stages, electronic money has the potential to shift the role of cash for retail payments because retail transactions can be made more easily and practically both for consumers and merchants (Abidin, 2015).

Crime in the circulation of counterfeit money is still frequently encountered, which of course with the existence of counterfeit money will harm the public, therefore Bank Indonesia often invites the public to immediately switch to using electronic money in conducting transactions to avoid counterfeit money, especially during feast days or other holidays. Advances in technology in the payment system have replaced the role of cash in the form of non-cash payments that are more efficient and economical. According to Pramono (2006), the banking and non-banking sectors are increasingly innovative in providing various alternative non-cash payment services in the form of transfer systems and payment instruments that use electronic cards (electronic card payments) that are safe, fast and efficient, and are global due to the development of information technology and followed by a higher level of bank competition. Counterfeit money is an imitation currency that is produced without legal approval from the state or government. Making, using, and circulating counterfeit money is very dangerous for a country's economy. Both on a 
market scale that is in direct contact with the community and large scale such as the occurrence of inflation (Hidayanto \& Afifah, 2015).

But in reality, using electronic money to avoid counterfeit money seems unproven. This is because there are still many people who use cash as transactions. The increase in cash used for transactions will allow for counterfeit money to be circulated in the community, based on data the money supply and the number of counterfeit rupiahs found that is increasing every year. Circulation of counterfeit money had decreased in 2017 because in 2016 Bank Indonesia issued new issuance of rupiah currency. But the circulation of counterfeit money increased again in 2018. Until December 2018 there were 16,17o bills found.

Counterfeiting of money still occurs. Large bills (IDR 50,000 and IDR 100,000) are the most commonly forged. In certain conditions, it is difficult for the public to pay attention to the characteristics of the authenticity of the rupiah, for example at the time of a transaction with a large value. Bringing cash in large amounts and large amounts of money are also very risky such as robbery, pickpocketing, mugging, and other forms of crime that can lurk the money bearers anytime and anywhere. Carrying large amounts of money is also very risky for mixing fake money. It certainly can be detrimental to society.

Microscale traders are more likely to be deceived by the presence of counterfeit money compared to modern outlets or stores such as minimarkets. This is due to equipment limitations, for example special ultraviolet lamps to check the authenticity of money. Micro traders like traders in the market rely solely on the sense of manual touch. To distinguish counterfeit money from real money, it is done in $3 \mathrm{D}$, which is seen, touched, and dreamed of. But in its application also can not be optimal, especially if the shanties are crowded with buyers so that the potential for circulation of counterfeit money can increase during rush hour. Like activities on the market, busyness often occurs in the morning, especially on weekends, so that conditions like this require traders to quickly serve the buyer and make transactions while the equipment to check one by one the authenticity of the money received is very minimal.

Based on the results of the multiple regression analysis conducted, there is a oneway relationship between economic growth and electronic money transactions that can be seen from the probability of economic growth smaller than 0.05. Economic growth has a positive effect significant impact on electronic money transactions in Indonesia, where increasing economic growth will further encourage electronic money transactions.

Economic growth is one of the methods used to see a country's prosperity and progress. Electronic money is also one of the results of a form of payment that is usually made by people with middle and upper classes, because in its use electronic money requires several components such as chip cards and smartphones. The use of electronic money shows a society that is open to technological and information advancements and applies it in all activities undertaken. So it can be said that more and more e-money users in a 
country, shows that the people in that country have sufficient income and are open to technology.

According to research by Olona Slozko (2014), it states that there is a clear interdependence between GDP growth and electronic transactions, in this case the rate of economic growth and financial system development will affect electronic money transactions, or payments without cash contribute to accelerating economic growth namely through the spread of electronic payments that can cause increased consumption. With the advantages possessed by electronic money, transactions that will be carried out by the public will be easier. Through smartphones, people can easily make transactions. So that with various facilities and benefits, it will increase public consumption.

Suseco (2016) states that electronic money will be used more as the economy grows. When economic growth increases it will also increase public transactions in using electronic money. Suseco also stated that in developing countries such as Indonesia, emoney has a positive and strong relationship with economies of scale. This matter means that e-money can become greater along with economic growth due to the increasing number of people whose level of prosperity is increasing and is considered technological literacy, so that they can accept new payment instruments in the form of electronic money and be able to use them in their daily lives. There is still potential for broad market share in developing countries with low incomes to increase electronic money users and encourage non-cash payment transactions. Therefore, electronic money grows well in developing countries.

Based on the results of the $\mathrm{F}$ Test on multiple regressions that have been done, the Prob (F-statistic) value of o.oooooo is obtained where the value is less than 0.05 and it can be stated that the money supply (Mi), counterfeit money, and economic growth together- the same positive and significant effect on electronic money transactions in Indonesia, especially in the period January 2016 December 2018. The test results of the coefficient of determination seen through the value of Adjusted R-Squared obtained results of 0.930082 which means the variable money supply (M1), counterfeit money and growth The economy is able to explain the electronic money transaction variable by 93 percent, while the rest that is by 7 percent is explained by other variables outside the model that are not examined.

\section{CONCLUSION}

Based on the results of data analysis and discussion of this study, the conclusions of this study are as follows: The money supply has a positive and significant effect on electronic money transactions in Indonesia. The results showed that the increase in electronic money transactions was also accompanied by an increase in the amount of money in circulation in the community. this is because there are still many people who use cash, which are then transferred to electronic money. Counterfeit money has no significant effect on transactions of electronic money in Indonesia. This is because the amount of money in circulation in the community continues to increase, where in the money 
supply there is the possibility of counterfeit money as Bank Indonesia data states that the ratio in 1000 bills circulated, there is 1 counterfeit currency that is also circulating in the community. Economic growth has a positive and significant effect on electronic money transactions in Indonesia. Non-cash payments contribute to accelerating economic growth through the spread of electronic payments which can cause increased public consumption. In addition, electronic money transactions in developing countries such as Indonesia have a positive and strong relationship with economies of scale, which means that electronic money transactions can be greater in line with economic growth, money supply (M1), counterfeit money, and economic growth together has a positive and significant effect on electronic money transactions in Indonesia and is able to explain the electronic money transaction variable by 93 percent.

Based on the results in this study, the following suggestions can be given: The government should reduce interest rates to increase the money supply in the community to increase electronic money transactions. However, to avoid inflation the money supply must be kept under control; holding socialization to the public regarding the use of electronic money and its advantages, one of which is that in using electronic money, fake money will not be found. Even though counterfeit money has no significant influence, its existence will harm the state and society; as well as making various efforts to encourage economic growth in order to increase electronic money transactions, such as improving the quality of human resources, accepting the development of science and technology, opening new jobs, increasing investment, encouraging exports, and improving infrastructure, and to increase electronic money transactions, Bank Indonesia together with the government and banks are expected to increase the money supply, reduce the circulation of counterfeit money, and increase economic growth.

Also, in its application, there is some electronic money that still has shortcomings such as security issues. Suggestions for emoney issuing companies, it is better for emoney that has not been given security to be given security, such as the PIN contained in the ATM so that when the e-money is lost it will not be misused by others who find it so that the owner will not lose the balance contained in it.

\section{REFERENCES}

Abidin, M. S. (2015). The Impact of E-Money Policy in Indonesia as a New Payment System Tool. Jurnal Akuntansi Unesa, 3.

Bawono, A. (2006). Multivariate Analysis Dengan SPSS. Salatiga: Stain Salatiga Press.

Boediono. (2009). Theories of Economic Growth.Yogyakarta: BPFE Yogyakarta.

Boediono, D. (2001). Synopsis Series Introduction to Economics No.2. Yogyakarta: BPFE Yogyakarta.

Direktorat Akunting dan Sistem Pembayaran, \& Direktorat Pengedaran Uang. (2008). Payment System and Money Circulation Reports. Jakarta.

Ghozali, I. (2013). Multivariate Analysis Application with SPSS Program. Semarang: Badan Penerbit Universitas Diponegoro.

Hidayanto, F., \& Afifah, Y. N. (2015). Education on Introduction of Counterfeit Money and How to Differentiate It from Real Money. Jurnal Inovasi Dan Kewirausahaan, 4, No 1, 9-12. 
Inria Zulfikar. (2018, January 31). EDITORIAL : Circulation of Counterfeit Money Ahead of the Local Election. Redaksi - Bisnis.com. Retrieved from

https://papua.bisnis.com/read/20180131/245/73243 2/editorial-peredaran-uang-palsu-jelang-pilkada

Lapong, P. R., Rotinsulu, T. O., \& Maramis, M. T. B. (2016). Analisis Kausalitas Amount of Money Supply and Bank Indonesia Reference Rate (BI Rate) in Indonesia Period 2009.1 - 2015.4. Jurnal Berkala Ilmiah Efisiensi, Volume 16, 278-287.

Lintangsari, N. N., Hidayati, N., Purnamasari, Y., Carolina, H., \& Febranto, W. (2018). Analysis of Non-Cash Payment Instruments for Financial System Stability in Indonesia. Dinamika Ekonomi Pembangunan, Vol 1 No 1 . Retrieved from https://ejournal.undip.ac.id/index.php/dinamika_ pembangunan/article/view/18772

Mankiw, N. G. (2006). Macroeconomics Sixth Edition (W. Hardani, D. Barnadi, \& S. Saat, Eds.). Jakarta: Erlangga.

Maqrobi, S., \& Pujiati, A. (2011). Inflation and Economic Growth : Uji Kausalitas Inflation And Economic Growth: Testing For Causality. Dinamika Keuangan Dan Perbankan, Vol. 3, No, 1-16.

Mishkin, F. S. (2008). Money Economics, Banking and Financial Markets (Buku 2). Jakarta: Salemba Empat.

Mujahidin, A. (2007). Ekonomi Islam. Jakarta: PT Raja Grafindo Persada.

Nadia Suci Anugrah. (2017). Analysis of Electronic Money Demand (E-money) in Indonesia.Universitas Diponegoro.

Olena Slozko, A. P. (2014). The Electronic Payments As A Major Factor For Futher Economic Development. Economics \& Sociology, Vol. 7, No.

Pramono, B., Yanuarti, T., Purusitawati, P. D., \& D.K., Y. T. E. (2006). The Impact of Non-Cash Payments on the Economy and Monetary Policy. Jakarta.

Prasetyo, P. E. (2009). Fundamental Makroekonomi. Yogyakarta: Beta Offset Yogyakarta.
Prathama, R., \& Mandala, M. (2008). Introduction to Economics (Microeconomics and Macroeconomics). Lembaga Penerbit Fakultas Ekonomi Universitas Indonesia.

Ramdani, D. D., Suryani, R., Gandana, Setyamarta, N., \& Aulina, L. (2014). Triple C (Centralize And Comprehensive Concept) As a Strategic Effort to Implement E-Money Indonesia. PKM-GT.

Siti Hidayati, Ida Nuryanti, A. F., \& Aulia Fadly, I. Y. D. (2006). E-money Operational Study.

Solikin, \& Suseno. (2002). Money Understanding, Creation, and Its Role in the Economy. Bank Indonesia Center for Central Bank Education and Study (PPSK), Central Bank Series. Retrieved from file://C:/Users/Asus/Downloads/1. Uang.pdf

Sova, K. (2013). Electronic Money Treends - User's perspective (Turku University of Applied Sciences).

Sukirno, S. (2011). Macroeconomics Introduction Theory (Issue 1). Jakarta: PT RajaGrafindo Persada.

Suseco, T. (2016). Effect of e-Money to Economic Performance (A Comparative Study of Selected Countries). The 2016 International Conference of Management Sciences.

Takiddin. (2014). Money In Islamic Perspective. SALAM: Jurnal Sosial Dan Budaya Syar-I, 206-212.

Tazkiyyaturrohmah, R. (2018). The Existence of Electronic Money as a Tool for Modern Financial Transactions. Muslim Heritage, Vol. 3, No.

Tazkiyyaturrohmah, R. (2018). EConsistency of Electronic Money as a Tool for Modern Financial Transactions. Jurnal IAIN Ponorogo, Vol. 3 No.

Utami, S. S., \& Kusumawati, B. (2017). Factors Affecting Interest in Using E-Money (Study at Ahmad Dahlan STIE Student Jakarta). Balance, Vol. XIV N.

Wahyudi, S. T. (2016). Concept and Application of Econometrics Using E-Views. Jakarta: PT RajaGrafindo Persada.

Wijayanto, A. A. (2017). Counterfeiting of Currency as a Crime in Indonesia. Jurnal Hukum Khaira Ummah, Vol. 12. N, 891-898. 